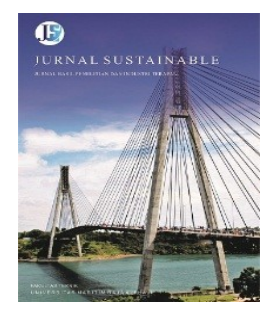

Jurnal Sustainable: Jurnal Hasil Penelitian dan Industri Terapan Vol. 09, No. 01, hal. 15- 22, Mei 2020

Jurnal Sustainable: Jurnal Hasil Penelitian dan Industri Terapan

ISSN 2615-6334 (Online) ISSN 2087-5347 (Print)

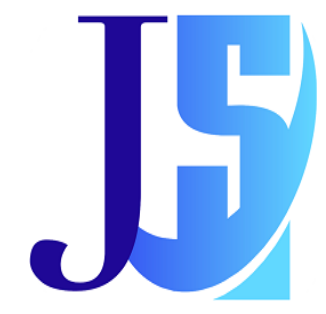

\title{
Analisa Crack Impeller Pada Fan Motor Assy
}

\author{
Rino Harco* \\ Jurusan Teknik Mesin, Fakultas Teknik, STT Wastukancana \\ J1. Cikopak No.53, Sadang, Purwakarta \\ *Corresponding Author: rinoharco@stt-wastukancana.ac.id
}

\begin{abstract}
Fan motors assy in the air conditioning system of the vehicle are one component that works to blow air into the vehicle room, and also serves to increase the air pressure volume that will be flowed in the vehicle room. In the assembly process of the motor motor assy the XXX model is by using a pressing method to combine the motor blower with the impeller, in the impeller pressing process, the reject product occurs which is crack in the impeller hole during the pressing process. This happens because the dimensions of the impeller are not standard, namely the dimensions of the hole in the impeller has experienced a shift deviation of $0.15 \mathrm{~mm}$ from the standard tolerance $\perp_{0.1}$ $\mathrm{mm}$. At $0.15 \mathrm{~mm}$ shift deviation, it is found that the slope of $1^{\circ}$ has the potential to crack in the impeller hole during the pressing process, because the material on the impeller PPGF-20, is unable to withstand the twisting force of $1.388 \mathrm{KN}$ when pressing process.
\end{abstract}

Keywords: Crack, Impeller, Pressing.

Intisari-Fan motor assy pada sistem pendingin udara pada kendaraan adalah salah satu komponen yang bekerja untuk menghembuskan udara ke dalam ruangan kendaraan, dan juga berfungsi juga sebagai untuk menaikkan atau memperbesar volume tekanan udara yang akan dialirkan dalam ruangan kendaraan. Pada proses perakitan Fan motor assy model XXX ini adalah dengan menggunakan metode pengepresan untuk menggabungkan antara motor blower dengan impeller, pada proses pengepresan impeller ini terjadi reject produk yaitu pecah pada bagian lubang impeller saat proses pengepresan. Hal ini terjadi dikarenakan dimensi pada impeller yang tidak standart yaitu dimensi lubang pada impeller telah mengalami penyimpangan pergeseran sebesar $\bar{x}$ $0.15 \mathrm{~mm}$ dari standard toleransi $\perp 0.1 \mathrm{~mm}$. Pada penyimpangan pergeseran $\bar{x} 0.15 \mathrm{~mm}$ ini mendapati kemiringan sudut $1^{\circ}$ berpotensi mengalami pecah pada bagian lubang impeller saat proses pengepresan yang dikarenakan material pada impeller yaitu PPGF-20 tidak mampu menahan besarnya gaya puntir lebih dari $1.388 \mathrm{KN}$ saat proses penekanan/pengepresan impeller.

Kata kunci : Impeller, Pengepresan, Pecah.

\section{Pendahuluan}

Dalam sebuah sistem pendingin udara pada kendaraan atau HVAC (Heating Ventilation Air Conditioning) dan sistem pendinginan ini dipergunakan untuk mempertahankan kondisi udara, baik temperatur dan kelembabannya dengan cara berikut :

1. Pada saat temperatur ruangan tinggi atau panas pada ruangan kendaraan maka air conditioner akan menyerap panas dari lingkungan sekitar sehingga temperatur disekitarnya akan turun atau dingin dan sebaliknya saat suhu disekitar turun maka air conditioner akan melepaskan panas ke udara sekitar dan temperatur udara akan naik.

2. Bersamaan dengan hal itu kelembaban udara berkurang sehingga kelembaban udara akan dipertahankan pada tingkat 
yang nyaman pada dalam ruangan kendaraan tersebut.

Dan salah satu komponen yang terdapat dalam sistem pendinginan udara yaitu fan motor assy/blower assy yang bertugas menghembuskan angin atau udara ke dalam ruangan mobil, yang juga berfungsi untuk menaikkan atau memperbesar tekanan udara yang akan dialirkan dalam ruangan kendaraan atau sebagai pengatur atau pengontrol volume udara dalam mobil.

Oleh sebab itu kualitas fan motor assy/blower assy harus dalam kondisi sempurna dan tidak boleh ada cacat produksi agar hembusan udara yang dihasilkan dapat bersirkulasi dengan baik, dan analisa ini dilakukan karena pada PT. VAI XXX terjadi kondisi abnormal proses pada perakitan fan motor assy/blower assy yaitu pada bagian lubang impeller telah terjadi retakan/pecah ketika sedang diproduksi yaitu pada saat proses pengepresan. Dan crack pada impeller ini mengakibatkan putaran impeller tidak balance yang mengakibatkan vibrasi/getaran pada hvac semakin besar dan berpotensi impeller tersebut dapat terlepas dari motor blower pada saat putaran/rpm tinggi.

\section{Metode Penelitian}

Dalam penyusunan tugas akhir ini, penulis menggunakan beberapa metode untuk mengumpulkan data yang diperlukan antara lain

\section{a. Penelitian Lapangan}

Penelitian ini merupakan metode pengumpulan data yang diperoleh langsung dari lapangan antara lain :

i. Observasi lapangan.

ii. Interview atau wawancara langsung.

b. Penelitian Kepustakaan

Merupakan metode pengumpulan data dari studi kepustakaan yang digunakan sebagai pedoman dalam bidang yang diambil.

c. Metode Korelasional

Pada metode korelasional, hubungan antara variable diteliti dan dijelaskan. Hubungan yang dicari ini disebut sebagai korelasi, jadi metode korelasional mencari hubungan diantara variabel-variabel yang diteliti.
Tujuan metode korelasi yaitu meneliti sejauh mana variabel pada satu faktor yang berkaitan dengan variasi pada faktor lainnya. Jika pada metode ini hanya dua variabel yang dihubungkan maka disebut korelasi sederhana dan jika lebih dari dua variabel dihubungkan disebut korelasi berganda. Pada metode ini pencarian hubungan (korelasi) antara dua variabel menggunakan koefisien korelasi atau ukuran yang menunjukan berapa banyak variasi dalam data dapat dijelaskan (koefisien determinasi). Point Analisa Penelitian Menggunakan Metode 4M.

Metode cause and effect ;

- Man

- Machine

- Method

- Material

\section{A. Pengujian Pada Mesin}

1) Pengecekan pressure pressing impeller

- Tujuannya untuk mengambil data penekanan impeller apakah sudah sesuai standard pengepresan.

- Dilakukan proses pengepresan dengan menggunakan mesin wheel inserting Janome Tipe JP504L dengan standard pressure pengepresan antara $1.1 \mathrm{KN}$ $2.8 \mathrm{KN}$.

- Alat yang digunakan untuk melihat hasil dari pengepresan adalah dengan melihat display pada mesin wheel inserting.

2) Pengecekan air pressure mesin

- Bertujuan untuk melihat supply air pressure pada mesin sudah sesuai standard.

- Dilakukan pengecekan air pressure pada mesin wheel inserting dengan standard tekanan $0.3 \mathrm{MPa}-0.5 \mathrm{MPa}$.

- Alat yang dipakai untuk menentukan tekanan udara pada mesin adalah dengan menggunakan air regulator.

3) Pengecekan alignment jig pada mesin

- Pengecekan ini bertujuan apakah jig impeller dan jig motor blower pada posisi alignment atau center pada mesin wheel inserting. 
- Pengujian ini dilakukan dengan cara mempertemukan antara pin pada jig impeller dengan shaft motor blower.

- Alat untuk pengujian ini adalah dengan menggunakan motor blower dan jig impeller.

\section{B. Pengujian Pada Material}

1) Pengukuran dimensi pada material

- Pengukuran ini bertujuan untuk mengetahui dimensi material apakah sesuai dengan standard.

- Dilakukan pengecekan pada setiap komponen fan motor assy pada bagian-bagian yang berpotensi adanya keabnormalan.

- Alat yang dipakai untuk mengukur material tersebut adalah dengan menggunakan alat ukur caliper digital.

Pengecekan nomor part material fan motor assy

- Pengecekan ini dilakukan untuk melihat apakah produk tersebut menggunakan part nomor yang sama sesuai standard.

- Dilakukan pengecekan dengan cara melihat nomor part yang ada di carton box ataupun yang ada di part tersebut.

- Cara yang dilakukan adalah dengan melihat secara visual part number tersebut apakah sesuai dengan Bill of Material atau BOM.

2) Pengukuran Coordinate Measuring Machine / CMM

- Pengukuran ini bertujuan untuk melihat dengan presisi dimensi aktual part impeller.

- Dilakukan pengukuran apakah sesuai dengan standard yang ada pada drawing pada part tersebut.

- Alat yang dipakai untuk mengukur part impeller tersebut adalah dengan menggunakan mesin Coordinate Measuring Machine atau CMM.

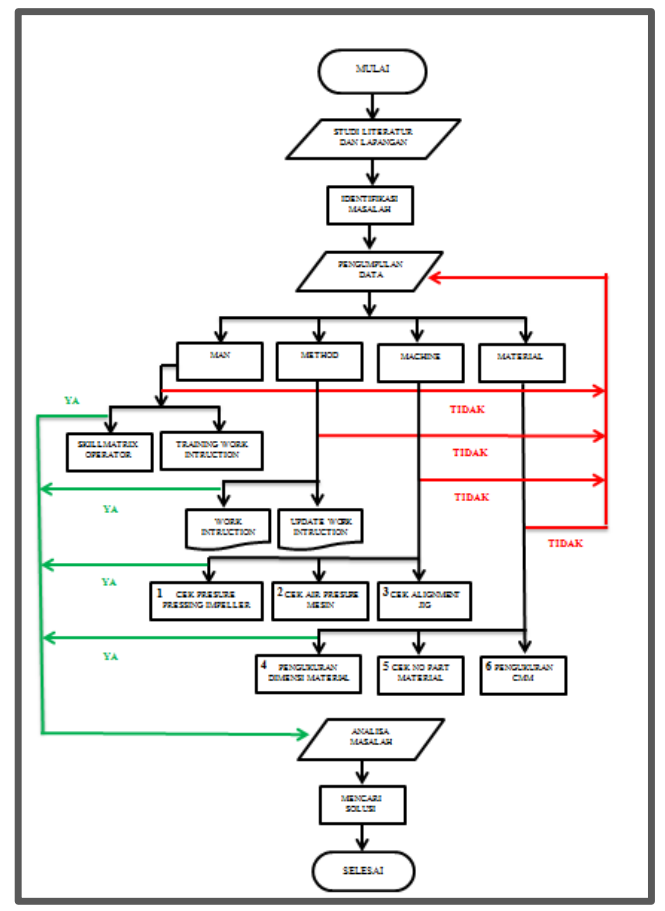

Gambar 1. Diagram alir penelitian.

\section{Hasil Dan Pembahasan}

\section{A. Analisa Metode Fishbone}

Pada analisa yang dilakukan pada metode 4 $\mathrm{M}$ dapat digambarkan menjadi diagram fishbone dan dapat dilihat pada Gambar 2 dan rangkuman diskusi terlihat pada Tabel 1 [4]

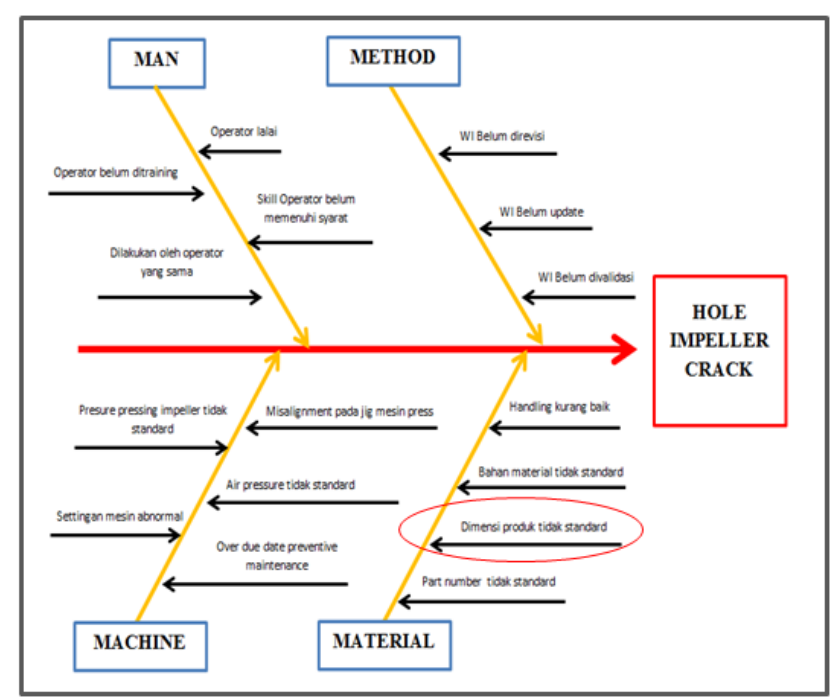

Gambar 2 Diagram fishbone. 
Tabel 1. Rangkuman diskusi terkait analisa fishbone

\begin{tabular}{|c|c|c|}
\hline Possible Root Cause & Discussion & Root Cause? \\
\hline \multicolumn{3}{|l|}{ MAN } \\
\hline Belum ditraining & Diberikan training WI & $\mathrm{N}$ \\
\hline Jumpingproses & Diberikan training WI & $\mathrm{N}$ \\
\hline Skill belum siap & Diberikan training WI & $\mathbf{N}$ \\
\hline \multicolumn{3}{|l|}{\begin{tabular}{|l|} 
METHOD \\
\end{tabular}} \\
\hline WI belum direvisi & WI sudah diupdate & $\mathbf{N}$ \\
\hline WI tidak update & WI sudah diupdate & $\mathbf{N}$ \\
\hline WI delum divalidasi & WI sudah divalidasi & $\mathbf{N}$ \\
\hline \multicolumn{3}{|l|}{ MACHINE } \\
\hline Low air pressure & Regulator tidak rusak & $\mathbf{N}$ \\
\hline Settingan parameter error & Cek mesin normal & $\mathbf{N}$ \\
\hline Misalignment pada mesin & Cek mesin normal & $\mathbf{N}$ \\
\hline Over Pressing & $\begin{array}{l}\text { Cek parameter mesin } \\
\text { normal }\end{array}$ & $\mathbf{N}$ \\
\hline Preventive maintenance & Tidak over due date & $\mathbf{N}$ \\
\hline \multicolumn{3}{|l|}{ MATERLAL } \\
\hline Handlingkurang baik & Diberikan training WI & $\mathbf{N}$ \\
\hline Material part & Material standard & $\mathbf{N}$ \\
\hline Dimensi produlk & Tidak sesuai drawing & $\mathbf{Y}$ \\
\hline Part number & $\begin{array}{l}\text { Part number sesuai } \\
\text { standard }\end{array}$ & $\mathbf{N}$ \\
\hline
\end{tabular}

\section{B. Analisa Pada Mesin}

1) Spesifikasi Mesin Pressing (Janome JP-

504L)

Mesin wheel inserting dengan tipe Janome JP-504L ini adalah mesin press yang digunakan untuk merakit fan motor assy yaitu dengan cara menekan impeller terhadap shaft motor sehingga impeller tersebut dapat terpasang. Berikut adalah spesifikasi mesin Janome JP-504L dapat dilihat pada Tabel 2 [1]

Tabel 2. Spesifikasi Mesin Janome JP-504L

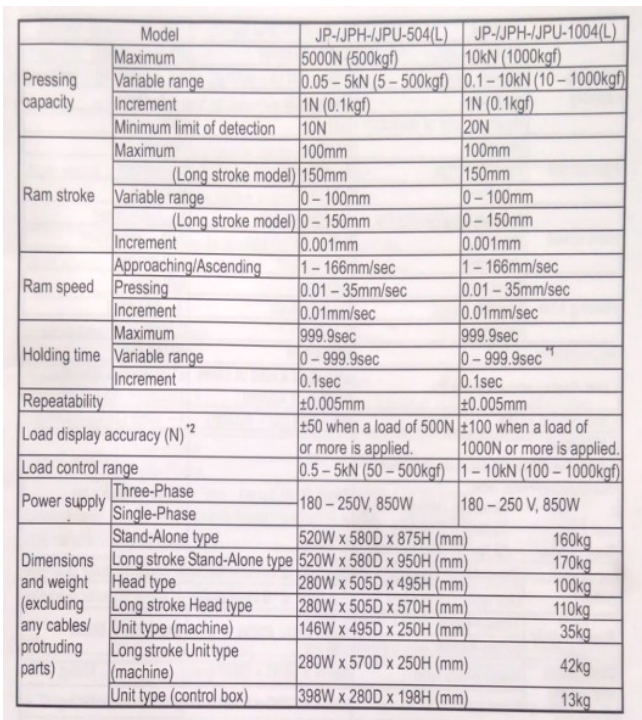

2) Analisa Tekanan Udara (Jig Motor Blower)

Untuk standard tekanan udara pada mesin wheel Inserting adalah $0.3 \mathrm{MPa}$ sampai $0.5 \mathrm{MPa}$, jika tekanan udara kurang ataupun lebih pada mesin akan berakibat posisi jig blower motor tidak akan sejajar pada jig impeller dan hal ini berakibat proses pengepresan abnormal yang berpotensi pada motor blower tidak sejajar terhadap lubang impeller, dan dapat dilihat pada Gambar 3 [6]

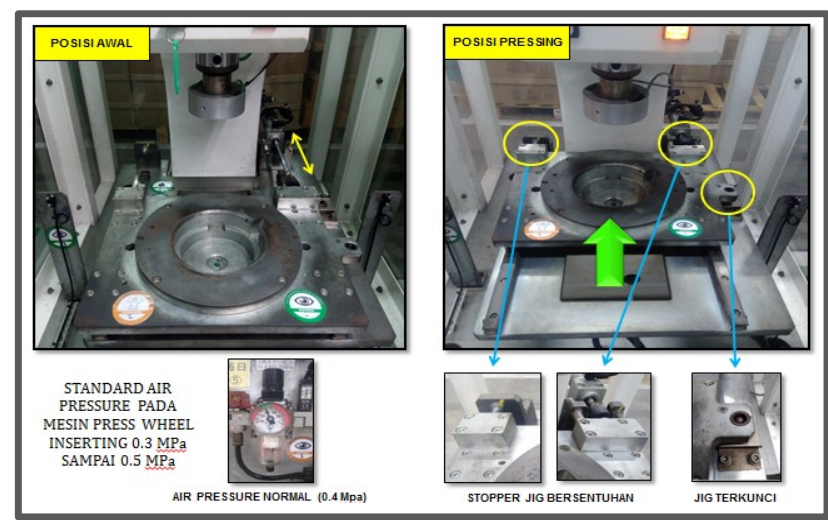

Gambar 3. Posisi jig saat proses pengepresan.

\section{3) Analisa Alignment Wheel Inserting Machine}

Pada analisa ini peneliti ingin memastikan apakah pada mesin wheel inserting bermasalah dikarenakan posisi antara jig impeller dengan jig motor blower tidak sejajar dan kesejajaran antara jig impeller dan jig motor blower dapat dilihat pada Gambar 4 [6]

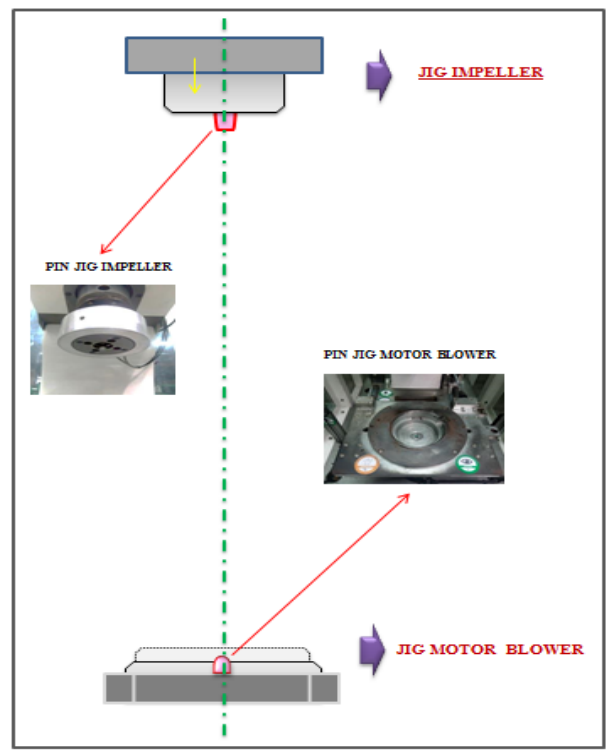

Gambar 4. Metode alignment. 


\section{4) Hasil analisa alignment mesin press}

Pada gambar tersebut dapat dilihat bahwa antara pin impeller dengan shaft pada motor touching atau bersentuhan dengan posisi yang sejajar/center. Dan dapat disimpulkan bahwa pada analisa penelitian yang dilakukan dengan metode alignment pada mesin press ini dinyatakan normal/ tidak berpotensi bermasalah dan dapat dilihat pada Gambar 5

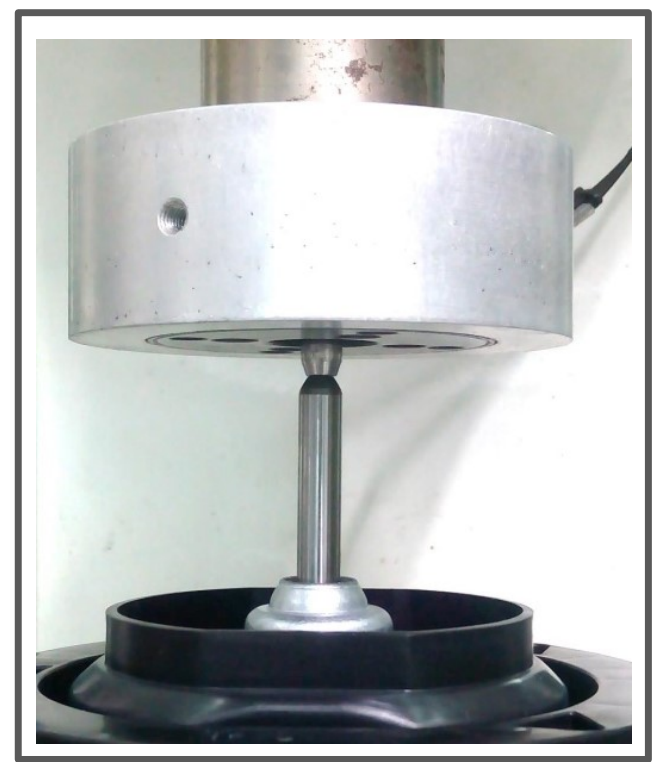

Gambar 5. Hasil penelitian metode alignment.

\section{Analisa Pada Material}

\section{1) Material Impeller}

Material yang dipakai untuk pembuatan impeller ini adalah PP-GF20 yang mempunyai arti polypropylene dengan campuran fiber glass sebesar $20 \%$ dan termasuk jenis plastik thermoplast yaitu adalah plastik yang dapat dicetak berulang-ulang dengan adanya panas. Polypropylene (pp) merupakan polimer kristalin yang dihasilkan dari proses polimerisasi gas propilena. Propilena mempunyai specific gravity rendah dibandingkan dengan jenis plastik lain. Dan polypropylene juga mempunyai titik leleh yang cukup tinggi $\left(190^{\circ} \mathrm{C}-200^{\circ} \mathrm{C}\right)$, sedangkan titik kristalisasinya antara $130^{\circ} \mathrm{C}-135^{\circ} \mathrm{C}$. Polypropylene mempunyai ketahanan yang baik terhadap bahan kimia (chemical Resistance) yang tinggi, akan tetapi didapati ketahanan pukul (impact strength) nya rendah. Berikut datasheet material impeller pp-gf20 pada Tabel 3 [7].
Tabel 3. Material impeller pp-gf20.

\begin{tabular}{|c|c|c|c|}
\hline $\begin{array}{l}\text { PHYSICAL } \\
\text { PROPERTIES }\end{array}$ & METRIX & ENGLISH & COMMENTS \\
\hline Density & $1.05 \mathrm{~g} / \mathrm{cc}$ & $0.0379 \mathrm{lb} / \mathrm{in}^{3}$ & ASTM D792 \\
\hline Water Absorption & $\begin{array}{c}0.010 \% \\
\text { atime } 86400 \mathrm{sec}\end{array}$ & $\begin{array}{c}0.010 \% \\
\text { @Time } 24.0 \text { hour }\end{array}$ & ASTM D570 \\
\hline $\begin{array}{c}\text { Linear Mold Shrinkage, } \\
\text { Flow } \\
\end{array}$ & $\begin{array}{c}0.0040 \mathrm{~cm} / \mathrm{cm} \\
\text { @Thickness } 3.17 \mathrm{~mm}\end{array}$ & $\begin{array}{c}0.0040 \mathrm{in} / \text { in } \\
\text { @ Thickness } 0.125 \mathrm{~m}\end{array}$ & ASTM D 955 \\
\hline $\begin{array}{l}\text { MECHANICAL } \\
\text { PROPERTIES }\end{array}$ & METRIX & ENGLISH & COMMENTS \\
\hline \begin{tabular}{|l|} 
Hardness, Rockwell R \\
\end{tabular} & 112 & 112 & ASTM D785 \\
\hline \begin{tabular}{|l|} 
Tensile Strength, Yield \\
\end{tabular} & $60.7 \mathrm{MPa}$ & $8800 \mathrm{psi}$ & ASTM D638 \\
\hline Elongation at Break & $5.0 \%$ & $5.0 \%$ & ASTM D638 \\
\hline \begin{tabular}{|l|} 
Flexural yield Strength \\
\end{tabular} & $96.5 \mathrm{MPa}$ & $14000 \mathrm{psi}$ & ASTM D790 \\
\hline Flexural Modulus & $3.10 \mathrm{GPa}$ & $450 \mathrm{ksi}$ & ASTM D790 \\
\hline Izod Impact, Notched & $\begin{array}{c}0.961 \mathrm{~J} / \mathrm{cm} \\
\text { @ } 9 \text { Thickness } 3.17 \mathrm{~mm}\end{array}$ & \begin{tabular}{|c|}
$1.80 \mathrm{ft}-\mathrm{lb} / \mathrm{in}$ \\
@ (h)ickness 0.125 in
\end{tabular} & ASTM D256 \\
\hline Izod Impact, Unnotched & $\begin{array}{c}8.54 \mathrm{~J} / \mathrm{cm} \\
\text { @ } 9 \text { Thickness } 3.17 \mathrm{~mm}\end{array}$ & \begin{tabular}{|c|}
$16.0 \mathrm{ft}-\mathrm{lb} / \mathrm{in}$ \\
@Thickness $0.125 \mathrm{in}$
\end{tabular} & ASTM D256 \\
\hline $\begin{array}{l}\text { ELECTRICAL } \\
\text { PROPERTIIES }\end{array}$ & METRX & ENGLISH & COMMENTS \\
\hline Volume Resistivity & $4.00 \mathrm{e}+160 \mathrm{hm}-\mathrm{cm}$ & $4.00 \mathrm{e}+160 \mathrm{hm}-\mathrm{cm}$ & ASTM D257 \\
\hline Dielectric Strength & $20.9 \mathrm{kV} / \mathrm{mm}$ & $530 \mathrm{kV} / \mathrm{in}$ & $\begin{array}{c}\text { Method A } \\
\text { (Short-Time) } \\
\text { ASTM D149 }\end{array}$ \\
\hline $\begin{array}{l}\text { THERMAL } \\
\text { PROPERTIES }\end{array}$ & METRIX & ENGLISH & COMMENTS \\
\hline $\begin{array}{c}\text { CTE, Linear, Parallel to } \\
\text { Flow } \\
\end{array}$ & $34.2 \mu \mathrm{m} / \mathrm{m}-{ }^{\circ} \mathrm{C}$ & $19.0 \mu \mathrm{in} / \mathrm{in}-{ }^{\circ} \mathrm{C}$ & ASTM D696 \\
\hline Melting Point & $163^{\circ} \mathrm{C}$ & $325^{\circ} \mathrm{F}$ & \\
\hline \begin{tabular}{|c|} 
Deflection Temperature \\
at $0.46 \mathrm{Mpg}(66 \mathrm{psi})$
\end{tabular} & $163^{\circ} \mathrm{C}$ & $325^{\circ} \mathrm{F}$ & $\begin{array}{l}\text { Unannesled. } \\
\text { ASTM D } 648 \\
\end{array}$ \\
\hline $\begin{array}{c}\text { Deflection Temperature } \\
\text { at } 1.8 \mathrm{Mpa}(264 \mathrm{psi})\end{array}$ & $154^{\circ} \mathrm{C}$ & $310^{\circ} \mathrm{F}$ & $\begin{array}{l}\text { Unannealed. } \\
\text { ASTM D } 648\end{array}$ \\
\hline Flammability, UL94 & $\mathrm{HB}$ & $\mathrm{HB}$ & \\
\hline
\end{tabular}

\section{2) Pengecekan Jig Go/No Go}

Pengecekan dengan menggunakan jig go/no go bertujuan untuk mengetahui apakah gap pada impeller masih masuk standard dan mengontrol kemiringan impeller saat terinstal pada motor blower terlihat pada Gambar 6

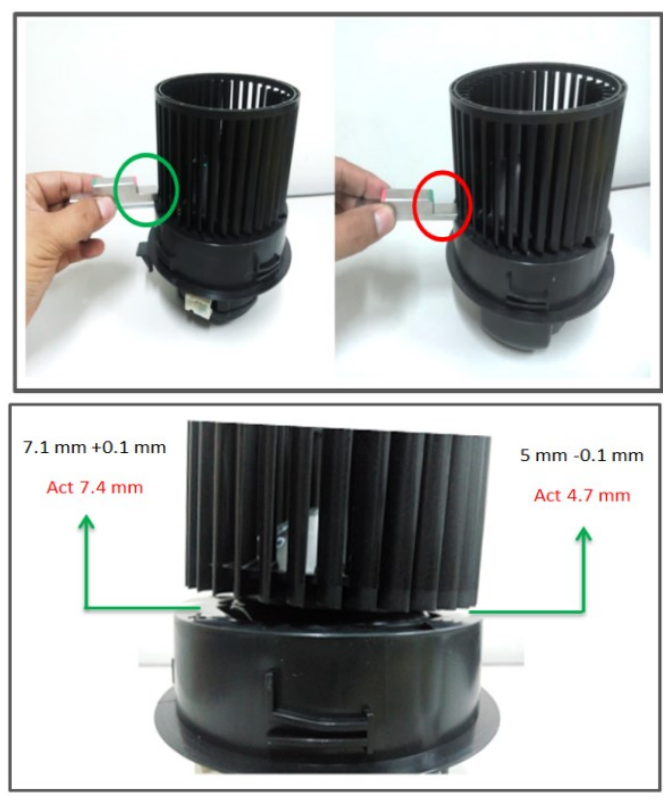

Gambar 6. Pengecekan jig go/no go. 


\section{3) Pengujian Menggunakan Mesin CMM}

Dari uji 4 sample untuk toleransi ketegaklurusan lubang impeller mempunyai nilai $\perp 0.1$ dan hasil dari pengukuran ada variasi kemiringan yang keluar dari dimensi pada drawing, dapat dilihat pada Gambar 7 dan Tabel 4

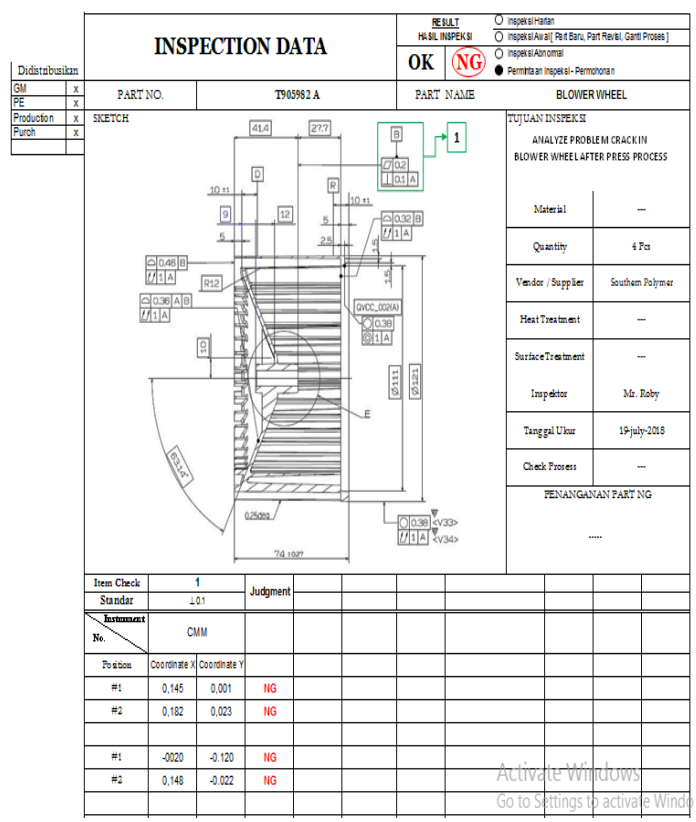

Gambar 7. Hasil pengukuran CMM.

Tabel 4. Hasil pengukuran $\mathrm{cmm}$

\begin{tabular}{|c|c|c|c|c|}
\hline \multirow{2}{*}{ POSITION } & \multirow{2}{*}{$\begin{array}{c}\text { Lot } \\
\text { Number }\end{array}$} & \multicolumn{2}{|c|}{ STANDARD $\perp 0.1(\mathrm{~mm})$} & \multirow{2}{*}{$\begin{array}{c}\text { JUDGEMENT } \\
\text { OK/NG }\end{array}$} \\
\hline & & COORDINATE $\mathrm{X}$ & COORDINATE Y & \\
\hline$\# 1$ & $17 \mathrm{C}$ & 0.145 & 0.001 & NG \\
\hline$\# 2$ & $19 \mathrm{C}$ & 0.182 & 0.023 & NG \\
\hline$\# 3$ & $26 \mathrm{C}$ & -0.020 & -0.120 & NG \\
\hline \#4 & $28 \mathrm{C}$ & 0.148 & -0.022 & NG \\
\hline
\end{tabular}

4) Simulasi lubang impeller keadaan miring

Berikut ini adalah gambar ketika impeller dalam keadaan miring dan ideal center pada fan motor assy, terlihat perbedaan jika lubang impeller miing maka shaft motor bersentukan terhadap disebagian dinding dan jika lubang impeller lurus maka shaft motor akan seimbang disisi-sisi dinding bagian dalam lubang impeller dan posisi tersebut dapat dilihat pada Gambar 8
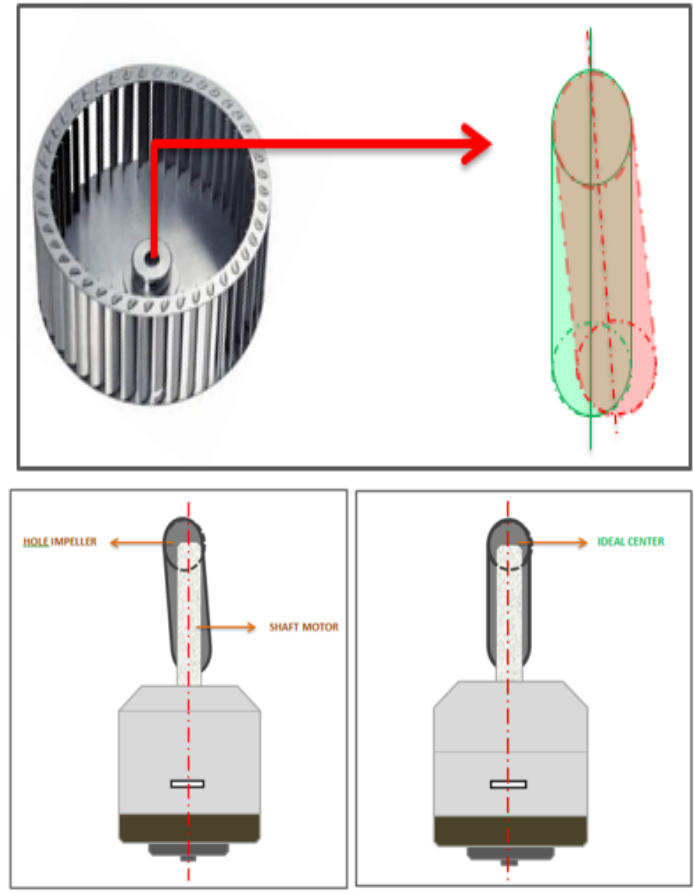

Gambar 8. Simulasi lubang impeller.

5) Perhitungan Gaya Yang Bekerja

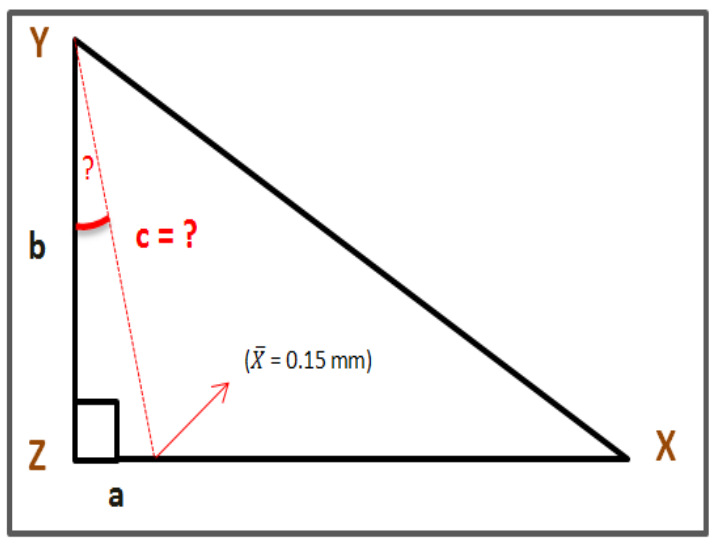

Gambar 9. Hasil pengukuran CMM.

Perhitungan mencari kemiringan garis (c) [3]

Pergeseran impeller $(\bar{X}=0.15 \mathrm{~mm})$ Tinggi lubang impeller $=28 \mathrm{~mm}$ Garis (c) ?

Perhitungan :

$$
\begin{aligned}
c^{2} & =a^{2}+b^{2} \\
c^{2} & =0.15^{2}+28^{2} \\
& =0.0225+784 \\
& =\sqrt{784.0225} \\
c \quad & =\mathbf{2 8 . 1} \mathbf{~ m m}
\end{aligned}
$$


$>$ Perhitungan mencari kemiringan sudut $(\mathrm{Y})$

Pergeseran impeller $\quad(\bar{X}=0.15 \mathrm{~mm})$

Tinggi lubang impeller $\quad=28 \mathrm{~mm}$

Sudut (c) $\quad=28.1 \mathrm{~mm}$

Sudut (Y) ?

Perhitungan :

$$
\begin{aligned}
\operatorname{Cos} Y & =\frac{b^{2}+c^{2}-a^{2}}{2 b c} \\
\operatorname{Cos} Y & =\frac{28^{2}+28.1^{2}-0.15^{2}}{2(28)(28.1)} \\
& =\frac{784+789.61-0.0225}{1573.6} \\
& =\frac{1573.587}{1573.6}
\end{aligned}
$$

$\operatorname{Cos} \mathrm{Y}=0.999 \quad \rightarrow \quad \mathrm{Y}=\mathbf{1}^{\circ}$

\section{Perhitungan gaya gesek [5]}

Berikut ini adalah perhitungan gesekan yang terjadi antara shaft motor blower dengan lubang impeller jika dalam kondisi tegak lurus/center :

$$
\begin{aligned}
& \mathrm{F}_{\text {gesek }}=P_{\text {impeller }} \times \mathrm{A}_{\text {shaft motor }} \\
& =P_{\text {impeller } \times} \pi r^{2} \\
& =2.4 .10^{3} \times \pi(3.9975)^{2} \times 10^{-6} \\
& =2.4 \times 3.14(3.9975)^{2} \times 10^{-3} \\
& =\mathbf{0 . 1 2 0 4} \mathbf{N} \quad \text { (normal) }
\end{aligned}
$$

Berikut ini adalah perhitungan gesekan yang terjadi antara shaft motor blower dengan lubang impeller jika dalam kondisi miring :

$$
\begin{aligned}
\mathrm{F}_{\text {gesek }} & =P_{\text {impeller }} \times \operatorname{Cos} \Theta \times \mathrm{A}_{\text {shaft motor }} \\
& =P_{\text {impeller }} \times 0.1^{\circ} \pi r^{2} \\
& =2.4 .10^{3} \times 0.999 \times \pi(3.9975)^{2} \times 10^{-6} \\
& =2.4 \times 0.999 \times 3.14(3.9975)^{2} \times 10^{-3} \\
& =\mathbf{0 . 1 2 0 3} \mathbf{N} \quad \text { (miring) }
\end{aligned}
$$

Perhitungan tegangan geser puntir

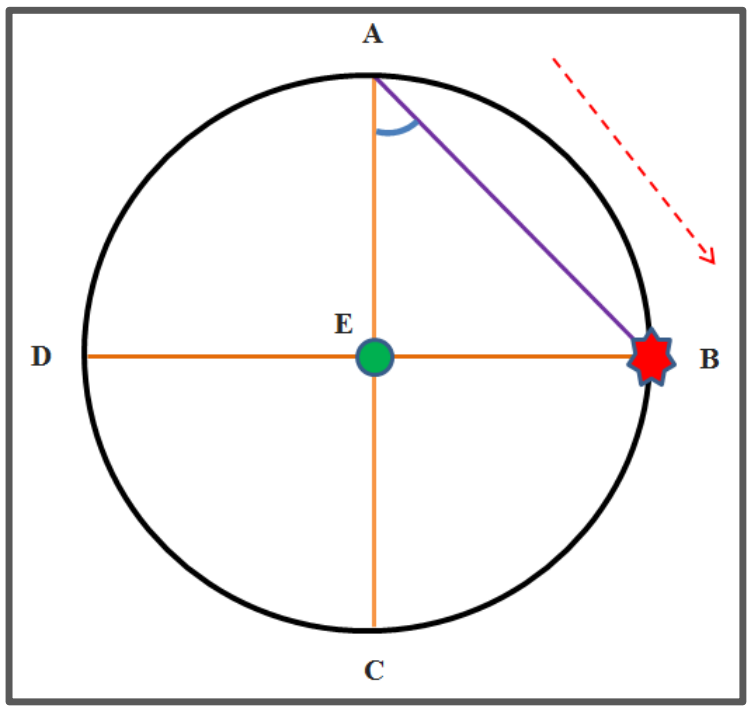

Gambar 10. Lingkaran mohr.

Berikut ini adalah hasil perhitungan tegangan geser puntir yang terjadi saat proses pengepresan yang berpotensi mengakibatkan crack pada bagian lubang impeller saat proses pengepresan. [7]

$$
\begin{aligned}
T_{\text {geser puntir }} & =\underline{F_{\text {impeller }}} \frac{\times \sin \theta \times r_{\text {impeller }}}{\pi \mathrm{d}_{\text {impeller }}^{4} / 32} \\
= & \frac{F_{\text {impeller }} \times 1^{\circ} \times r_{\text {impeller }}}{\pi\left(2 r_{\text {impeller }}\right)^{4}} \times 32 \\
= & \frac{2400 \times 0.0175 \times\left(60.5 \times 10^{-3)}\right.}{3.14\left(2 \times 60.5 \times 10^{-3}\right)^{4}} \times 32 \\
= & 120.82 \times 10^{3} \mathrm{~Pa}=\mathbf{1 2 0 . 8 2} \mathbf{~ K P a}
\end{aligned}
$$

Perhitungan gaya puntir

Berikut ini adalah hasil dari perhitungan gaya puntir yang terjadi saat proses pengepresan yang berpotensi menyebabkan pecah/crack pada bagian lubang impeller ketika saat proses pengepresan. [ 2 ]

$$
\begin{aligned}
\mathrm{F}_{\text {puntir }} & =\mathrm{T}_{\text {geser puntir }} \times \pi\left(\mathrm{r}_{\text {impeller }}\right)^{2} \\
& =120.82 \times 10^{3} \times 3.14\left(60.5 \times 10^{-3}\right)^{2} \\
& =120820 \times 3.14 \times\left(3660 \times 10^{-6}\right) \\
& =1388.5 \mathrm{~N}=\mathbf{1 . 3 8 8} \mathbf{K N}
\end{aligned}
$$




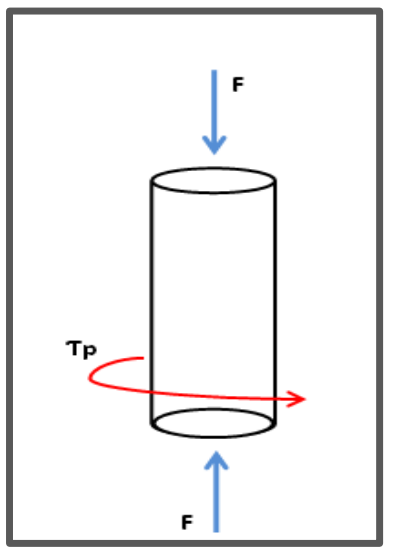

Gambar 11. Gaya puntir pada lubang impeller.

\section{KESIMPULAN}

Metode analisa penyebab impeller crack dilakukan dengan menggunakan metode $4 \mathrm{M}$ dan setelah dilakukan pengembangan penelitian terhadap main power dan method tidak berpotensi masalah dan potensi pada mesin press, yaitu pengecekan pada air presure, tekanan pada impeller dan alignment pada mesin press tidak ditemukan keabnormalan yang dapat berpotensi menyebabkan terjadinya crack pada lubang impeller. Setelah dilakukan pengecekan dan pengukuran pada material terkait maka hasilnya peneliti menemukan keabnormalan pada material, dimana dimensi pada part impeller tersebut sudah keluar dari spesifikasi yang telah ditetapkan oleh drawing/standard. Faktor yang berpotensi menyebabkan terjadinya crack pada lubang impeller yaitu dikarenakan posisi pada bagian bawah lubang impeller telah mengalami pergeseran sebesar $\bar{X} \perp=0.15 \mathrm{~mm}$ dari standard $\perp 0.1 \mathrm{~mm}$. Dan pergeseran tersebut yang menyebabkan ketika proses pengepresan impeller terhadap motor blower akan berpotensi pecah / crack pada bagian lubang impeller dikarenakan material pada impeller tidak mampu menahan gaya puntir sebesar $1.388 \mathrm{KN}$.

\section{UCAPAN TERIMA KASIH}

Terima kasih disampaikan kepada para karyawan PT XXX yang telah mensupport serta membantu memberikan data-data yang diperlukan dalam penelitian ini.

\section{REFERENSI}

[1] Operation manual specifications janome electro press jp4series / 22 / Janome Sewing Machine Co., Ltd.- Tokyo, Japan. january 2009.

[2] Joseph Edward Shigley. Larry D. Mitchell Perencanaan Teknik Mesin. Edisi ke Empat (Jilid 1) Jakarta. Erlangga.1999.

[3] Buku ajar fisika jilid 1, (17- 18)1.Fisika dasar-digital library uwp-Universitas WijayaPutra pdvlibrary.uwp.ac.id. Diakses 25 Mei 2018.

[4] Purba, H.H. (2008, September 25). Diagram Fishbone dari Ishikawa. Retrieved from (hardipurba.com /2008/09/25/ diagramfishbone-dari-ishikawa.html). Diakses 03 Juli 2018.

[5] E.P.Popov. Mekanika Teknik Edisi kedua (Versi S1). Jakarta: Erlangga. 1996.

[6] Piotrowski, John, Shaft alignment handbook. Third Edition. New York. by Taylor \& Francis Group, LLC. 1952.

[7]Matweb.http://www.matweb.com/search/ datasheet.aspx? matguid Diakses 03 Juli 2018. 